\title{
Firm Factors and Share Returns of Secondary Equity Offers at Nairobi Securities Exchange, Kenya
}

\author{
Kenneth Marangu ${ }^{1}$, Stephen Muathe ${ }^{1}$ \& Lucy Mwangi ${ }^{1}$ \\ ${ }^{1}$ School of Business, Kenyatta University, Nairobi, Kenya \\ Correspondence: Kenneth Marangu, School of Business, Kenyatta University, Nairobi, Kenya. E-mail: \\ kmmarangu@gmail.com
}

Received: April 11, 2019

Accepted: May 13, 2019

Online Published: May 20, 2019

doi:10.5539/ijef.v11n6p107

URL: https://doi.org/10.5539/ijef.v11n6p107

\begin{abstract}
This paper provides an empirical analysis of the effect of firm factors namely size, profitability, leverage and shareholding structure on share returns of secondary equity offers at Nairobi Securities Exchange in Kenya. An event study employing the market model determined share returns of 52 bonus issues and 28 rights issues announced between January 2006 and December 2015. Multivariate linear regression analysis established the effect of size, profitability, leverage and shareholding structure on share returns of secondary equity offers obtained from the event study. The results of the event study indicate that secondary equity offer announcements had a significant positive effect on share returns and thus investors increased their wealth during the event period. The results of multivariate linear regression analysis revealed that profitability and shareholding structure had a significant positive effect on share returns, size had a significant negative effect on share returns while leverage did not affect share returns. The study recommends investors to participate in secondary equity offers of small sized profitable companies with a high proportion of institutional investors because they will realize positive share returns and increase their wealth. The study further recommends management of small sized and profitable companies with a high proportion of institutional investors to raise capital through secondary equity offers as this will increase their market capitalization. The Capital Markets Authority and Nairobi Securities Exchange should consider size, profitability and shareholding structure when screening companies seeking approval to raise capital through secondary equity offers.
\end{abstract}

Keywords: event study, firm factors, Nairobi Securities Exchange, secondary equity offers, share returns

\section{Introduction}

\subsection{Secondary Equity Offers}

Companies listed on Nairobi Securities Exchange fund viable investments by raising capital from a wide array of internal and external sources including debt from commercial banks, development financial institutions and corporate bonds and equity from retained earnings and equity offers (Nickels, Mc Hugh, \& Mc Hugh, 2012). An equity offer entails the issue of new additional shares by a company to existing shareholders or potential investors. Equity offers can take the form of private offers where transactions between companies and investors occur outside of the capital markets or public offers executed through the capital markets (Eitman, Stonehill, \& Moffet, 2013).

Two common classes of public equity offers at Nairobi Securities Exchange are initial public offers and secondary equity offers. During an initial public offer, shares of a company are availed to the public on a securities exchange for the very first time, transforming a private company into a public company. During a secondary equity offer, a company whose shares already trade in a securities exchange increases its share capital by creating and issuing new additional shares. Secondary equity offers are open to existing shareholders, new investors or a hybrid of both existing shareholders and new investors (Wright \& Sylla, 2013).

The most common types of secondary equity offers at Nairobi Securities Exchange are bonus issues and rights issues. A bonus issue entails issuance of free additional new shares in a company. Bonus issues are used as an alternative to or in addition to a cash dividend and do not result to dilution in shareholding because a shareholder's proportional ownership of the company is not altered.

A rights issue is an invitation to current shareholders to acquire additional new shares in a company based on 
their proportion of current shareholding. Rights issues are priced at a discount and existing shareholders have an option of exercising their rights and participating in the rights issue or renouncing their rights and selling them to potential investors through the securities exchange (Wright \& Sylla, 2013).

\subsection{Share Returns of Secondary Equity Offers}

The investment principle as espoused by Keringler and Lee (2000) postulates that the key objective of investors is to earn returns. Returns on an investment compensate investors for the opportunity cost arising from the time value of money, the reduction in the purchasing power of money and the risk that the amount of money invested will not be recouped at the end of the investment period (Reilly \& Brown, 2011).

In securities exchanges, share returns of secondary equity offers can be neutral, positive or negative. Neutral share returns are based on the premise that secondary equity offer announcements do not affect share prices which is anchored on the efficient market hypothesis and Modigliani and Miller capital irrelevance theory. Positive share returns assume that secondary equity offer announcements lead to an increase in share prices, which is consistent with the arguments of the static trade off theory and agency cost theory. Negative share returns are an indication that the secondary equity offer announcements result to a decrease in share prices as explained by the pecking order theory and the information asymmetry hypothesis.

When companies raise capital through secondary equity offers, management's key objective is to increase the market value of the company, which is only achievable if market share prices increase leading to a higher market capitalization. Management prefers high market capitalization because the shares of a company trade as blue chips, the company is able to obtain credit and debt under favorable terms and conditions, the company is well positioned to grow through acquisition of competitors and the company will attain the status of being a market leader (Reilly \& Brown, 2011).

When investors participate in secondary equity offers, their main objective is to increase their wealth, which is only realized if there is a corresponding increase in share prices that results to positive share returns. Therefore, investors prefer to participate in secondary equity offers that result to an increase in share prices or positive share returns since this will lead to capital gains if the investment in shares is sold at the prevailing market prices or an increase in the value of the investment if the shares are held to the long term.

Management and investors are cognizance that share prices are affected by factors such as the market forces of demand and supply in capital markets, prevailing capital market conditions, investor risk assessment of individual companies, industry specific factors and company specific factors. Consequently, management and investors are very keen on the effect of secondary equity offer announcements on share returns including the factors that affect share returns of secondary equity offers.

Malhotra, Thenmozhi, and Arunkumar (2013) document that share returns of secondary equity offers are affected by macro-economic factors, market factors, offer structure factors and firm factors. Kogan and Papanikolaou (2012) point out that there is strong empirical evidence supporting the co-movement of share returns of companies listed in securities exchanges that have similar characteristics, tendencies and features. They linked cross sectional differences in share returns to firm factors that were common among companies listed in security exchanges.

Bessembinder and Zhang (2012) report that share returns of secondary equity offers do not require to be explained using economic factors, market factors or offer structure factors because firm factors can sufficiently provide the explanations. In line with this argument, researchers in developed and emerging capital markets have explained share returns of secondary equity offers using firm factors such as size, age, leverage, liquidity, profitability, risk and shareholding structure.

Whilst these past studies report that numerous firm factors affect share returns of secondary equity offers, they are not conclusive on the number of firm factors or the specific firm factors that affect share returns of secondary equity offers. Developed and emerging capital markets have different characteristics from developing capital markets in relation to assets, liquidity, size, activity and risks and thus important to establish the effect of firm factors on share returns of secondary equity offers in a developing capital market in Sub Saharan Africa such as Nairobi Securities Exchange.

At Nairobi Securities Exchange, there is dearth of empirical literature on the factors that affect share returns of secondary equity offers. Olesaaya (2010), Kithinji, Oluoch, and Mugo (2014), Ndungu (2014), Ogada (2014), Otieno (2014) and Mariko and Theuri (2016) studied secondary equity offers at Nairobi Securities Exchange but only focused on establishing whether share returns of secondary equity offers were significant or non-significant and whether the secondary equity offer announcements had a neutral, positive or negative effect on share returns. 
Consequently, these studies do not inform management and investors at Nairobi Securities Exchange on the factors that affect share returns of secondary equity offers. Information on the factors that affect share returns of secondary equity offers assists management to identify factors that they should monitor and control to improve company share prices during secondary equity offer periods. This information also informs investors on the factors that they should monitor and track so that they can increase their wealth when they participate in secondary equity offers.

This study therefore examined firm factors that affect share returns of secondary equity offers at Nairobi Securities Exchange in Kenya. Examining these firm factors informs on whether management of Nairobi Securities Exchange listed companies and investors on Nairobi Securities Exchange utilise financial information to support informed decision-making. This study also sought to establish whether share returns of secondary equity offers at Nairobi Securities Exchange could be explained by firm factors that were identified as being significant in developed and emerging capital markets.

\subsection{Study Objectives and Hypotheses}

The general objective of this study was to investigate the effect of firm factors on share returns of secondary equity offers at Nairobi Securities Exchange in Kenya. The specific objectives of this study were as follows:

a) To establish the effect of size on share returns of secondary equity offers at Nairobi Securities Exchange, Kenya

b) To determine the effect of profitability on share returns of secondary equity offers at Nairobi Securities Exchange, Kenya

c) To examine the effect of leverage on share returns of secondary equity offers at Nairobi Securities Exchange, Kenya

d) To assess the effect of shareholding structure on share returns of secondary equity offers at Nairobi Securities Exchange, Kenya

The study tested the following hypotheses aligned with the specific objectives:

$\mathrm{H}_{01}$ : Size does not significantly affect share returns of secondary equity offers

$\mathrm{H}_{02}$ : Profitability does not significantly affect share returns of secondary equity offers

$\mathrm{H}_{03}$ : Leverage does not significantly affect share returns of secondary equity offers

$\mathrm{H}_{04}$ : Shareholding structure does not significantly affect share returns of secondary equity offers

\section{Literature Review}

\subsection{Theoretical Literature Review}

Fama and French (1963) developed a three-factor asset pricing model that build on the capital asset pricing model by postulating market risk, value and size as the factors that affect share returns of companies. This model takes cognizance of the fact that value (low price to book value ratio) and small size (low capitalization) companies witness higher share returns than the markets on a regular basis. Since small sized companies are expected to have higher share returns than large sized companies, the Fama and French three-factor model hypothesizes a negative relationship between size and share returns of secondary equity offers.

According to Gordon (1962), a company that is on a growth trajectory will increase its earnings capability and generate adequate future cash flows at a consistent growth rate. This implies that when the profitability of a company increases, investors' increase their valuation of the company shares and this leads to an increase in the market price of shares. A sustained increase in the market price of shares ultimately results to positive share returns. Therefore, the Gordon growth model hypothesizes a positive relationship between profitability and share returns of secondary equity offers.

According to Myers (1984), the tax shield advantage of debt increases with increases in the level of leverage such that the value of a levered company is equal to the value of an unlevered company plus the tax shield advantage of debt. Therefore, when companies conclude secondary equity offers, company leverage decreases and investors in the capital market revise the valuation of the tax shield advantage of debt downwards. When the tax shield advantage of debt is lowered, the value of a company decreases and this leads to a decrease in market share prices or negative share returns. Therefore, the static trade off theory hypothesizes a positive relationship between leverage and share returns of secondary equity offers.

According to Jensen and Meckling (1976), institutional investors invest enormous funds in companies, they are 
professional in nature and thus they regularly monitor the performance of companies. Consequently, a company with a high proportion of institutional investors will incur increased monitoring costs, which will lead to improved performance. Improved company performance results to increases in share prices and positive share returns. Therefore, the agency cost theory hypothesizes a positive relationship between a high proportion of institutional investors and share returns of secondary equity offers.

\subsection{Empirical Literature Review}

Onclin (2014) reports that rights issue announcements had a negative effect on share returns in the Dutch Securities Market during the period 2001 to 2013. The study used a sample size of 34 and employed the event study methodology and the market model to estimate expected share returns, which this study adopted. Ramesh and Rajumesh (2014) document that rights issue announcements had a positive effect on share returns at Colombo Stock Exchange in Sri Lanka during the period 2008 to 2012. Using a sample of 78 events, the event study methodology and the market model were employed which were both adopted in this study.

Mariko and Theuri (2016) detailed that rights issue announcements had a neutral effect on share returns at Nairobi Securities Exchange during the period 2004 to 2013. The study does not reconcile the high mean abnormal share returns of between 0.66 and 0.73 that had an overall neutral effect. Otieno (2014) reports that rights issue announcements had a negative effect on share returns at Nairobi Securities Exchange during the period 2007 to 2014. The study used a small sample size of 12, did not perform diagnostic tests and failed to explain the drivers of the negative effect.

Ndungu (2014) documents that rights issue announcements had a positive effect on share returns at Nairobi Securities Exchange during the period 2009 to 2013. The study used a small sample size of eight and a short time period of five years. Mbui (2016) established that bonus issue announcements had a positive effect on share returns at Nairobi Securities Exchange during the period 2010 to 2014. The study used a small sample size of five, a short time period of five years and a short event window period of 15 days. Both studies failed to explain factors that drive the positive effect of secondary equity offer announcements.

Agarwal and Mohanty (2012) observed that size had a significant and positive effect on share returns of rights issues in India. The study employed an event study, the market model and multivariate linear regression analysis approaches, which this study adopted. Velayutham (2015) reported that size had an insignificant and positive effect on share returns of secondary equity offers announced by companies listed on the Colombo Stock Exchange. The study adopted an event study methodology and multivariate linear regression analysis, which were applied in this study.

Abraham and Harrington (2011) observed that profitability had a significant and positive effect on share returns of secondary equity offers in USA. They study employed logistic regression analysis to develop a model to predict the characteristics of companies that undertake secondary equity offers using firm factors. Tahir, Sabir, Alam and Ismail (2013) confirmed that profitability had a significant and positive effect on share returns of secondary equity offers in Pakistan. The study adopted an event study methodology and multivariate linear regression analysis, which this study employed.

Huang (2012) reported that leverage had a significant and negative effect on share returns of secondary equity offers in China. The study adopted an event study and the market model, which this study adopted. Malhotra, Thenmozhi and Arunkumar (2013) established that leverage had a significant and negative effect on share returns of bonus and rights issues in India. The study adopted an event study methodology, mulivariate linear regression analysis and the market model approaches, which this study applied.

Owen and Suchard (2009) report that the proportion of institutional investors had a significant and positive effect on share returns of secondary equity offers in Australia. The study employed an event study, market model and multivariate linear regression analysis methodologies, which this study adopted. Lerskullawat (2011) established that companies with a high proportion of institutional investors have a low probability of raising capital through secondary equity offers in Thailand. The study does not inform on the effect of the proportion of institutional investors on share returns of secondary equity offers.

Owen and Suchard (2009), Lerskullawat (2011), Agarwal and Mohanty (2012), Huang (2012), Malhotra, Thenmozhi, and Arunkumar (2013), Tahir, Sabir, Alam, and Ismail (2013) and Velayutham (2015) did not perform diagnostic tests and thus failure to perform adequate statistical procedures could have affected the study results and findings.

Research on companies listed on Nairobi Securities Exchange does not inform management and investors on the factors that affect share returns of secondary equity offers at Nairobi Securities Exchange. Research in developed 
and emerging capital markets reports that numerous firm factors affect share returns of secondary equity offers but is not conclusive on the number of firm factors or the specific firm factors that affect share returns of secondary equity offers. This study was therefore carried out to address this reaserch gap.

\section{Research Methodology}

\subsection{Research Design}

This study adopted an explanatory research design because it sought to establish the effect of firm factors on share returns of secondary equity offers. According to Kerlinger and Lee (2000), an explanatory research design is appropriate where a researcher attempts to explain how phenomena operates by pointing out the fundamental factors that cause change under circumstances where the study variables are not managed.

\subsection{Population of the Study}

The target population of this study was 80 secondary equity offers comprising of 52 bonus issues and 28 rights issues announced by companies listed on Nairobi Securities Exchange between January 2006 and December 2015. A target population of 80 secondary equity offers is a small population and thus this study adopted a census approach. According to Saunders, Lewis, and Thornhill (2009), a census approach enhances the validity of the data collected because it includes a complete data set that will lead to a high degree of statistical confidence in the study results.

\subsection{Data Analysis}

This study utilized secondary data on share prices, announcement dates of secondary equity offers and firm factors extracted from daily equity price lists, daily market reports provided by Nairobi Securities Exchange and audited financial statements and annual reports published by listed companies. A document review guide and data abstraction tool were used to extract and compile the required data for analysis. Data extracted from the data abstraction tool was entered into Microsoft Excel spreadsheets where it was coded depending on the company and the type of secondary equity offer (bonus issues and rights issues).

An event study following the Brown and Warner (1985) methodology was carried out to determine abnormal share returns. The event study covered the period 20 trading days before and 20 trading days after the announcement of a secondary equity offer. The event study entailed determining actual share returns, determining expected share returns, calculating abnormal share returns and determining the significance of the abnormal share returns.

Actual share returns can be calculated using logarithmic models and simple return models. Meucci (2012) observes that in empirical finance, logarithmic return models are preferred over simple return models to calculate actual share returns because they can be construed as continuously compounded returns. Continuous compounding of expected log returns provides a better guide to the future cumulative returns. This study therefore adopted Model (1) to compute actual share returns where the holding period was equated to one trading day at Nairobi Securities Exchange.

$$
A S R_{i t}=\log \left(P_{1}-P_{0}\right) / \log P_{0}
$$

Where

$\mathrm{ASR}_{\mathrm{it}}=$ Actual share returns of company $i$ at time $t$;

$\mathrm{P}_{1}=$ Price at the end of the holding period;

$\mathrm{P}_{0}=$ Price at the beginning of the holding period;

Log = Natural logarithim.

According to Brown and Warner (1985), price models and market models can be used to estimate expected share returns. Medeiros and Matsumoto (2005) point out that price models possess intricate econometric issues such as non-stationarity of price series and thus return models are preferred and commonly applied in financial research. The market return Model (2) was used to compute expected share returns and is based on the assumption of a constant and linear relationship between individual share returns and the return on a market index.

$$
E S R_{i t}=\alpha+\beta_{i} R M+\varepsilon_{i t}
$$

Where

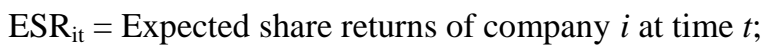

$\alpha=$ Return of the share when there is no change in the market returns;

$\beta_{\mathrm{i}}=$ Beta coefficient of company $i$; 
$\mathrm{RM}=$ Return on Nairobi Securities Exchange twenty share index;

$\varepsilon_{\text {it }}=$ Error term.

Abnormal share returns were calculated using Model (3) as specified by Brown and Warner (1985) and later adopted by Onclin (2014).

$$
S R_{i t}=A S R_{i t}-E S R_{i t}
$$

Where

$\mathrm{SR}_{\mathrm{it}}=$ Abnormal share returns of company $i$ at time $t$;

$\mathrm{ASR}_{\mathrm{it}}=$ Actual share returns of company $i$ at time $t$;

$\mathrm{ESR}_{\mathrm{it}}=$ Expected share returns of company $i$ at time $t$.

Abnormal share returns were computed for each trading day in the event period. The individual trading day's abnormal share returns were summed to compute the cumulative abnormal share returns during the event period using Model (4) as specified by Brown and Warner (1985).

$$
C A S R=\Sigma D A S R
$$

Where:

CASR $=$ Cumulative abnormal share returns;

DASR $=$ Daily abnormal share returns.

The cumulative abnormal share returns obtained from Model (4) were averaged to obtain the average cumulative abnormal share returns using Model (5) as specified by Brown and Warner (1985).

$$
A C A S R=1 / N * C A S R
$$

Where:

ACASR $=$ Average cumulative abnormal share returns;

$\mathrm{N}=$ Number of observations in the sample;

CASR $=$ Cumulative abnormal share returns.

To establish the significance of abnormal share returns, there was need to determine whether the average cumulative abnormal share returns were statistically different from zero. This procedure used at test statistic and tested the null hypothesis that the average cumulative abnormal share returns were not significantly different from zero during the event period. To test the hypothesis, a critical $t$ value read from the $t$ distribution table was compared to a calculated t value based on the adjusted average cumulative abnormal share returns that were derived using Model (6). Model (6), referred to as the standardized residual t test, was developed by Patell (1976).

$$
T_{\text {Patell }}=A C A S R / \sigma A C A S R
$$

Multivariate linear regression analysis was applied to establish the effect of firm factors namely size, profitability, leverage and shareholding structure on the average cumulative abnormal share returns as specified by Model (7).

$$
S R=\alpha+\beta_{1} \text { Size }_{i t}+\beta_{2} \text { Profit }_{i t}+\beta_{3} \text { Leverage }_{i t}+\beta_{4} \text { Share }_{i t}+\varepsilon_{i t}
$$

Where

$\mathrm{SR}=$ Average cumulative abnormal share returns;

$\alpha=$ Constant term;

$\beta_{1}, \beta_{2}, \beta_{3}$, and $\beta_{4}=$ Coefficients of size, profitability, leverage and shareholding structure;

Size $_{\text {it }}=$ Size of company $i$ at time $t$;

Profit $_{\mathrm{it}}=$ Profitability of company $i$ at time $t$;

Leverage $_{\text {it }}=$ Leverage of company $i$ at time $t$;

Share $_{\text {it }}=$ Shareholding structure of company $i$ at time $t$;

$\varepsilon_{\mathrm{it}}=$ Error term.

The $\mathrm{F}$ test, adjusted $\mathrm{R}^{2}$, and the $\mathrm{t}$ test were performed to test for how well the data fitted into the model, overall significance of the model and significance of the individual independent variables respectively. Hypothesis testing was carried out at $95 \%$ confidence level ( $5 \%$ significance level, $\alpha=0.05$ ). 


\subsection{Diagnostic Testing}

Tests for normality, heteroscedasticity, autocorrelation, multicollinearity and stationarity were carried out prior to running Model (7) to ensure that the assumptions of the classical linear regression model were not violated. According to Brooks (2008), applying linear regression models when the assumptions of the classical linear regression model are violated results to biased, inefficient and inconsistent parameter estimates.

\subsection{Operation and Measurement of Study Variables}

Table 1 provides a summary of the study variables, their operational definitions and the measurements used to estimate these variables. The measures adopted in this study were used and validated by previous researchers.

Table 1. Operation and measurement of study variables

\begin{tabular}{lll}
\hline Variable & Operationalization & Measurement \\
\hline Share returns & $\begin{array}{l}\text { Abnormal share returns: A measure of how actual share returns } \\
\text { differ from expected share returns. }\end{array}$ & Average cumulative abnormal share returns \\
$\begin{array}{l}\text { Firm size } \\
\text { Profitability }\end{array}$ & $\begin{array}{l}\text { Market capitalisation. Total market value of all company shares. } \\
\text { Return on assets: The profit generated by each shilling of assets } \\
\text { invested in a company. }\end{array}$ & $\begin{array}{l}\text { Log (market price per share * total number of issued shares) } \\
\text { Debt to equity ratio. The proportion of equity and debt a company Total debt/total equity }\end{array}$ \\
Leverage & $\begin{array}{l}\text { is using to finance its assets. } \\
\text { Shareholding }\end{array}$ & $\begin{array}{l}\text { Institutional investor concentration. The proportion of } \\
\text { structure }\end{array}$ \\
\hline
\end{tabular}

Source: Researcher.

\section{Research Findings and Discussion}

\subsection{Descriptive Statistical Analysis Results}

\subsubsection{Study Response Rate}

The sample analysed in this study comprised of all Nairobi Securities Exchange listed companies that had announced secondary equity offers between January 2006 and December 2015. The study considered secondary equity offers namely bonus issues and rights issues. During the ten-year period, 41 listed companies announced 80 secondary equity offers comprising of 52 bonus issues and 28 rights issues. In this study, the researcher covered all the 52 bonus issues and all the 28 rights issues, which translated to 100 percent coverage. Coverage of 100 percent was achieved because the study relied on secondary data that was extracted from daily equity price lists, weekly equity price lists, daily market reports, weekly market reports provided by Nairobi Securities Exchange, annual financial reports, half year financial reports and monthly economic review reports published by the Central Bank of Kenya which were all available.

\subsubsection{Sample Characteristics}

The characteristics of the sample studied were as presented in Table 2.

Table 2. Sample charactristics

\begin{tabular}{lccccc}
\hline Period & Bonus Issues & Rights Issues & Total & \% Bonus Issues & \% Rights Issues \\
\hline $2006-2010$ & 25 & 10 & 35 & $71 \%$ & $29 \%$ \\
$2011-2015$ & 27 & 18 & 45 & $60 \%$ & $40 \%$ \\
Total & $\mathbf{5 2}$ & $\mathbf{2 8}$ & $\mathbf{8 0}$ & $\mathbf{6 5 \%}$ & $\mathbf{3 5 \%}$ \\
\hline
\end{tabular}

Source: Research Data, 2015.

Bonus issues and rights issues comprised of 65 percent and 35 percent respectively of the total secondary equity offers announced by listed companies during the period January 2006 to December 2015. This implied that at Nairobi Securities Exchange, companies prefered to raise equity capital through bonus issues when compared to rights issues because bonus issues are free as opposed to rights issues offered at a price consideration. In addition, listed companies opt for bonus issues instead of paying cash dividends, which attract withholding tax and have the effect of reducing company cash flows. Furthermore, bonus issues do not alter the shareholding structure of a company and thus have no dilution effect. 


\subsection{Diagnostic Test Results}

\subsubsection{Normality Test Results}

The Shapiro Wilk (1965) test was performed to test the null hypothesis that the study data was normal. The test results were as presented in Table 3.

Table 3. Normality test results

\begin{tabular}{lcc}
\hline Variable & Z statistic & P value \\
\hline Share returns & 0.675 & 0.0983 \\
Firm size & 0.457 & 0.3021 \\
Profitability & 2.10 & 0.2017 \\
Leverage & 1.032 & 0.6345 \\
Shareholding structure & 1.467 & 0.0712 \\
\hline
\end{tabular}

Source: Research Data, 2015.

The $\mathrm{Z}$ statistics of all the study variables reported $\mathrm{p}$ values $>0.05$ and hence failure to reject the null hypothesis. This implied that the study data was in the order required to conduct hypothesis tests about the model parameters and tests requiring normality of the data such as $t$ tests were reliable to make statistical inferences.

\subsubsection{Heteroscedasticity Test Results}

The Breusch Pagan (1979) chi square test was performed to test the null hypothesis that the variance of the error terms were not heteroscedastic or not changing over time. The test results were as presented in Table 4.

Table 4. Heteroscedasticity test results

\begin{tabular}{lcc}
\hline Variable & Chi value & P value \\
\hline Share returns & 0.77 & 0.3817 \\
Firm size & 0.43 & 0.5231 \\
Profitability & 1.21 & 0.1487 \\
Leverage & 2.16 & 0.1418 \\
Shareholding structure & 1.94 & 0.1633 \\
\hline
\end{tabular}

Source: Research Data, 2015.

The chi statistics of all the study variables reported $\mathrm{p}$ values $>0.05$ and hence failure to reject the null hypothesis. This implied that the variance of the error terms were not heteroscedastic or not changing over time thereby making the standard errors appropriate for testing the significance of the coefficients.

\subsubsection{Autocorrelation Test Results}

The Durbin Watson (1951) test was performed to test the null hypothesis that the study data had no autocorrelation. The test results were as presented in Table 5 .

Table 5. Autocorrelation test results

\begin{tabular}{lc}
\hline Variables & DW Statistic \\
\hline Share returns & 1.92 \\
Firm size & 1.66 \\
Profitability & 1.93 \\
Leverage & 1.89 \\
Shareholding structure & 1.54 \\
Average & $\mathbf{1 . 6 6}$ \\
\hline
\end{tabular}

Source: Research Data, 2015.

The average test statistic of all the study variables was reported at 1.66 which is within the neighborhood of its center of distribution $(\mathrm{d}=2.0)$ and hence failure to reject the null hypothesis. This implied that the error terms of the study variables were not related and the coefficients that would be obtained from the regression model would be best, linear and unbiased estimators. 


\subsubsection{Multicollinearity Test Results}

The Variance Inflation Factor test was performed to test for multicollinearity in the study data using a tolerable Variance Inflation Factor of less than 10 as recommended by Field (2009). The test results were as presented in Table 6.

Table 6. Multicollinearity test results

\begin{tabular}{lcc}
\hline Variable & Variance Inflation Factor & Remarks \\
\hline Firm size & 4.86 & No multicollinearity \\
Profitability & 1.32 & No multicollinearity \\
Leverage & 1.03 & No multicollinearity \\
Shareholding structure & 4.35 & No multicollinearity \\
\hline
\end{tabular}

Source: Research Data, 2015.

All the independent variables had Variance Inflation Factor values $<10$ and hence conclusion that multicollinearity was tolerable. This implied that individual coefficients obtained from the regression models would not have high standard errors and the regression models would not be sensitive to small changes in the model specification.

\subsubsection{Stationarity Test Results}

The Phillips Perron (1988) test was performed to test the null hypothesis that the study data was not stationary. The test results were as presented in Table 7.

Table 7. Stationarity test results

\begin{tabular}{lcccc}
\hline Variable & Test Statistic & $\mathbf{1 \%}$ Critical & 5\% Critical & 10\% Critical \\
\hline Share returns & -7.247 & -3.563 & -2.920 & -2.595 \\
Firm size & -4.586 & -3.563 & -2.920 & -2.595 \\
Profitability & -6.718 & -3.563 & -2.920 & -2.595 \\
Leverage & -4.539 & -3.563 & -2.920 & -2.595 \\
Shareholding structure & -4.150 & -3.563 & -2.920 & -2.595 \\
\hline
\end{tabular}

Source: Research Data, 2015.

All the study variables had critical values at $1 \%, 5 \%$ and $10 \%$ significance levels, which were less than the computed test statistic and hence the rejection of the null hypothesis. This implied that all the study variables were stationary and thus applying the ordinary least squares regression methodology would not result to spurious regressions.

\subsection{Event Study Results}

Prior to performing multivariate linear regression analysis, an event study following the Brown and Warner (1985) methodology was carried out to determine share returns of secondary equity offers. A summary of the average cumulative abnormal share returns of secondary equity offers during the event period were as shown by Table 8 .

Table 8. Average cumulative abnormal share returns

\begin{tabular}{cc}
\hline Parameter & Value \\
\hline Mean & 0.0122 \\
Standard Deviation & 0.0179 \\
Standard Error & 0.0027 \\
Calculated T & 4.379 \\
$\mathrm{t}_{0.05 / 2,41}$ & 2.021 \\
\hline
\end{tabular}

Source: Research Data, 2015.

A positive mean of the average cumulative abnormal share returns was an indication that during the periods 20 days before announcement and 20 days after announcement of secondary equity offers, the market prices of shares were on average increasing. The tabulated statistics (critical value) $=2.021<4.379$ (calculated t statistics), 
implied that the average cumulative abnormal share returns of secondary equity offers were significantly different from zero and thus secondary equity offers announcements affected share returns.

This was an indication that at Nairobi Securities Exchange, investors were earning abnormal share returns during the secondary equity offer period, which implied that market share prices were increasing significantly and investors were increasing their wealth. This further implied that secondary equity offer announcements had a positive effect on share returns and thus investors at Nairobi Securities Exchange perceive secondary equity offer announcements to be good news, which leads to an increase in share prices and share returns.

\subsection{Multivariate Linear Regression Analysis Results}

Multivariate linear regression analysis established the effect of firm factors on share returns of secondary equity offers obtained from the results of the event study. The results of the multivariate linear regression analysis were as presented in Table 9.

Table 9. Multivariate linear regression results

\begin{tabular}{lccc}
\hline Variable & Coefficient & T statistic & P value \\
\hline Size & 0.0000091 & -2.37 & 0.022 \\
Profitability & 0.337 & 16.56 & 0.000 \\
Leverage & 0.0959 & 0.13 & 0.894 \\
Shareholding structure & 0.313 & 3.61 & 0.001 \\
Constant & 0.007 & 2.04 & 0.048 \\
Observations & 80 & & 0.000 \\
R squared & 0.897 & & \\
Adjusted R squared & 0.888 & & \\
F statistic & 98.34 & & \\
\hline
\end{tabular}

Source: Research Data, 2015.

An adjusted $\mathrm{R}^{2}$ of 0.888 implied that size, profitability, leverage and shareholding structure had a high explanatory power because they jointly accounted for $88.8 \%$ variation in share returns of secondary equity offers. The F statistic of 98.34 , with $\mathrm{p}$ value $=0.000<0.05$ indicated that size, profitability, leverage and shareholding structure were jointly significant in explaining variations in share returns of secondary equity offers.

Size had a coeffecient of $\beta=-0.0000091$, with $\mathrm{p}$ value $=0.022<0.05$, hence rejection of $\mathbf{H}_{01}$ at the $95 \%$ confidence level $(\alpha=0.05)$. The study concluded that size had a significant and negative effect on share returns of secondary equity offers. The coefficient of -0.0000091 implied that when all the other firm factors are held constant, a unit increase in size would result to a decrease in share returns of 0.0000091 .

These findings do not concur with empirical studies carried out by Agarwal and Mohanty (2012) and Tepe (2012) who reported that size had a significant and positive effect on share returns of secondary equity offers in India and Turkey respectively. However, the study findings were consistent with the arguments of the Fama and French three-factor model as advanced by Fama and French (1993) which hypothesizes that size has a negative effect on share returns of secondary equity offers.

Profitability had a coefficient of $\beta=0.337$, with $\mathrm{p}$ value $=0.000<0.05$, hence rejection of $\mathbf{H}_{\mathbf{0 2}}$ at the $95 \%$ confidence level $(\alpha=0.05)$. The study concluded that profitability had a significant and positive effect on share returns of secondary equity offers. The coefficient of 0.337 implied that when all the other firm factors are held constant, a unit increase in profitability would result to an increase in share returns of 0.337 .

These findings supported empirical studies carried out by Abraham and Harrington (2011), Besembinder and Zhang (2012), Er and Vuran (2012), Huang (2012), Tahir, Sabir, Alam and Ismail (2013) and Velayutham (2015) who reported that profitability had a significant and positive effect on share returns of secondary equity offers in USA, Canada, Turkey, China, Pakistan and Sri Lanka respectively. The study findings were consistent with the Gordon growth model as documented by Gordon (1962) which hypothesizes that profitability has a positive effect on share returns of secondary equity offers.

Leverage had coefficient of $\beta=0.0959$, with $\mathrm{p}$ value $=0.894>0.05$, hence failure to reject $\mathbf{H}_{\mathbf{0 3}}$ at the $95 \%$ confidence level $(\alpha=0.05)$. The study concluded that leverage did not affect share returns of secondary equity offers. These findings were not consistent with empirical studies carried out by Abraham and Harrington (2011), Agarwal and Mohanty (2012), Huang (2012), Onclin (2014) and Velayutham (2015) who reported that leverage 
had a significant and positive effect on share returns of secondary equity offers in USA, India, China, Turkey and Sri Lanka respectively. The study findings were not consistent with the static trade off theory as proposed by Myers (1984) which hypothesizes that leverage has a positive effect on share returns of secondary equity offers.

Shareholding structure had a coefficient of $\beta=0.313$, with $p$ value $=0.001<0.05 p$ value of 0.001 , hence rejection of $\mathbf{H}_{04}$ at the $95 \%$ confidence level $(\alpha=0.05)$. The study concluded that shareholding structure had a significant and positive effect on share returns of secondary equity offers. The coefficient of 0.313 implied that when all the other firm factors are held constant, a unit increase in the proportion of institutional investors would result to an increase in share returns of 0.313 .

These findings supported empirical studies carried out by Owen and Suchard (2009) and Huang (2012) who reported that the proportion of institutional investors had a significant and positive effect on share returns of secondary equity offers in Australia and China respectively. These findings were also consistent with the agency cost theory associated with Jensen and Meckling (1976) which hypothesizes that institutional investors have a positive effect on share returns of secondary equity offers.

Based on the results of the study, Model (7) was specified as follows:

$$
S R=0.007-0.0000091 \text { Size }_{i t}+0.337 \text { Profit }_{i t}+0.313 \text { Share }_{i t}+\varepsilon_{i t}
$$

Where:

$\mathrm{SR}=$ Share returns of secondary equity offers

Size $_{\mathrm{it}}=$ Firm size of company $_{\mathrm{i}}$ at time ${ }_{\mathrm{t}}$

Profit $_{i t}=$ Profitability of company $_{i}$ at time $_{t}$

Share $_{\mathrm{it}}=$ Shareholding structure of company $_{\mathrm{i}}$ at time $\mathrm{t}_{\mathrm{t}}$

\section{Conclusion and Recommendations}

\subsection{Conclusion}

The study concluded that at Nairobi Securities Exchange, secondary equity offer announcements had a significant and positive effect on share returns. Investors perceived secondary equity offer announcements to be good news because during the event period, market share prices increased significantly, share returns were positive and investors increased their wealth. This study also concluded that profitability and proportion of institutional investors had a significant and positive effect on share returns of secondary equity offers, size had a significant and negative effect on share returns of secondary equity offers while leverage did not affect share returns of secondary equity offers.

\subsection{Recommendations}

The study recommends that managers of Nairobi Securities Exchange listed companies continue raising equity capital through secondary equity offers because this will lead to an increase in share prices and the market value of companies. Investors are encouraged to participate in secondary equity offers because they will increase their wealth. Managers of companies listed on Nairobi Securities Exchange that are small size, profitable and have a high proportion of institutional investors should raise capital through secondary equity offers because this will lead to increase in share prices and market capitalization. Investors on Nairobi Securities Exchange should participate in secondary equity offers of companies that are small size, profitable and have a high proportion of institutional investors because this will lead to positive share returns and an increase in investor wealth. The Capital Markets Authority and Nairobi Securities Exchange should use size, profitability and shareholding structure to screen companies making applications to raise capital through secondary equity offers.

\section{References}

Agarwal, A., \& Mohanty, P. (2012). The Impact of Rights Issues on Stock Returns in India. Asia Pacific Finance and Accounting Review, 1(1), 5-16.

Bessembinder, H., \& Zhang, F. (2012). Firm Characteristics and Long run Stock Returns after Corporate Events. Paper Presented at University of Alberta Frontiers in Finance Conference, Canada. https://doi.org/10.2139/ssrn.2097989

Bollerslev, T. (1986). Generalized Autoregressive Conditional Heteroscedasticity. Journal of Econometrics, 3(3), 307-327. https://doi.org/10.1016/0304-4076(86)90063-1

Brooks, C. (2008). Introductory Econometrics for Finance. Cambridge: Cambridge University Press. https://doi.org/10.1017/CBO9780511841644 
Brown, S., \& Warner, J. (1985). Using Daily Stock Returns: The Case of Event Studies. Journal of Financial Economics, 14(1), 3-31.

De Angelo, H., De Angelo, L., \& Stulz, R. M. (2009). Seasoned Equity Offerings, Market Timing and Corporate Life Cycle. Journal of Financial Economics, 95(3), 275-295. https://doi.org/10.1016/j.jfineco.2009.11.002

Durbin, J., \& Watson, G. S. (1951). Testing for Serial Correlation in Least Squares Regression. Biometrika, 38(2), 159-71. https://doi.org/10.1093/biomet/38.1-2.159

Eitman, D. K., Stonehill, A. I., \& Moffet, M. H. (2013). Multinational Business Finance. New York: Prentice Hall.

Engle, R. F. (1982). Autoregressive Conditional Heteroscedasticity with Estimates of the Variance of United Kingdom Inflation. Econometrica, 50(4), 987-1007. https://doi.org/10.2307/1912773

Er, S., \& Vuran, B. (2012). Factors Affecting Stock Returns of Firms Quoted in Istanbul Stock Exchange Market: A Dynamic Panel Data Approach. International Journal of Business and Social Research, 2(1), 109-122.

Fama, E. (1998). Market Efficiency, Long Term Returns and Behavioral Finance. Journal of Financial Economics, 49(3), 283-306. https://doi.org/10.1016/S0304-405X(98)00026-9

Fama, E. F., \& French, K. (1992). The Cross Section of Expected Stock Returns. Journal of Finance, 47, 427-465. https://doi.org/10.1111/j.1540-6261.1992.tb04398.x

Fama, E. F., \& French, K. R. (1993). Common Risk Factors in the Returns on Stocks and Bonds. Journal of Financial Economics, 33(1), 3-56. https://doi.org/10.1016/0304-405X(93)90023-5

Field, A. P. (2009). Discovering Statistics using IBM SPSS Statistics. London: Sage Publications.

Gordon, M. J. (1962). The Investment, Financing, and Valuation of the Corporation. Homewood, IL: R. D. Irwin.

Hess, A. C., \& Frost, P. A. (1982). Tests for Price Effects of New Issues of Seasoned Securities. Journal of Finance, 37(1), 11-25. https://doi.org/10.1111/j.1540-6261.1982.tb01092.x

Huang, Z. (2012). Seasoned Equity Offerings in China (Doctor of Philosophy Dissertation). Retrieved from http://eprints.soas.ac.uk/13813

Jensen, M. C., \& Meckling, W. H. (1976). Managerial Behavior, Agency Costs and Ownership Structure. Journal of Financial Economics, 3(4), 305-360. https://doi.org/10.1016/0304-405X(76)90026-X

Kamanja, B. (2014). The Effects of Bonus Issue Announcements on Share Prices of Commercial Banks Listed on Nairobi Securities Exchange (Unpublished Dissertation). University of Nairobi, Kenya.

Kerlinger, F. H., \& Lee, H. B. (2000). Foundations of Behavioral Research. New York: Harcourt College Publishers.

Kirui, E., Wawire, H. W., \& Onono, P. O. (2014). Macroeconomic Variables, Volatility and Stock Returns: A Case of Nairobi Securities Exchange Kenya. International Journal of Economics and Finance, 6(8), 214-228. https://doi.org/10.5539/ijef.v6n8p214

Kithinji, J. G., Oluoch, W., \& Mugo, W. (2014). The Effect of Rights Issue on Firm Share Performance at Nairobi Securities Exchange. Research Journal of Finance and Accounting, 5(4), 76-84.

Kogan, L., \& Papanikolaou, D. (2012). A Theory of Firm Characteristics and Stock Returns: The Role of Investment Specific Shocks. National Bureau of National Research, 17975, 1-67. https://doi.org/10.3386/w17975

Lerskullawat, P. (2011). Seasoned Equity Offerings in an Emerging Market: Evidence from Thailand (Unpublished Dissertation). University of Birmingham, United Kingdom.

Malhotra, M., Thenmozhi, M., \& Arunkumar, C. (2013). Factors Influencing Abnormal Returns Around Bonus and Rights Issue Announcements. Journal of Applied Finance, 19(4), 41-60. Retrieved from https://EconPapers.repec.org/RePEc:icf:icfjaf:v:19:y:2013:i:4:p:41-60

Mariko, J. B., \& Theuri, J. M. (2016). Effect of New Information from Rights Issue Announcements on Share Prices of Firms Listed on Nairobi Securities Exchange. American Journal of Finance, 1(4), 54-70.

Mbui, A. L. (2016). Effect of Bonus Issue Announcements on Share Returns of Companies Listed on Nairobi Securities Exchange (Unpublished Dissertation). University of Nairobi, Kenya.

Medeiros, O. R., \& Matsumoto, A. S. (2005). Brazilian Market Reaction to Equity Issue Announcements. 
Brazilian Administration Review, 2, 35-46. https://doi.org/10.1590/S1807-76922005000200004

Meucci, A. (2010). Linear Versus Compounded Return Calculations: Common Pitfalls in Portfolio Management. GARP Risk Management, 40-43.

Miglani, P. (2011). An Empirical Analysis of Impact of Right Issues in the Indian Listed Companies. Journal of Arts, Science and Commerce, 2, 169-176.

Myers, S. C. (1984). The Capital Structure Puzzle. Journal of Finance, 39, 575-592. https://doi.org/10.1111/j.1540-6261.1984.tb03646.x

Myers, S. C., \& Majluf, N. S. (1984). Corporate Financing and Investment Decisions. Journal of Financial Economics, 13(2), 187-221. https://doi.org/10.3386/w1396

Ndungu, P. N. (2014). The Effect of Rights Issue Announcement on Share Prices of Companies Listed at Nairobi Securities Exchange (Unpublished Dissertation). University of Nairobi, Kenya.

Nickels, W. G., Mc Hugh, J. M., \& Mc Hugh, S. (2012). Understanding Business. New York: Irwin.

Olesaaya, E. (2010). The Effects of Rights Issue on Stock Returns. Case study of Companies Listed at Nairobi Securities Exchange (Unpublished Dissertation). University of Nairobi, Kenya.

Onclin, N. (2014). An Investigation to the Announcement Impact from Right Issues on Stock Prices in the Dutch Capital Market (Unpublished Dissertation). University of Twente, Netherlands.

Otieno, D. (2014). The Effects of Rights Issue Announcements on Stock Returns of Firms Listed on Nairobi Securities Exchange (Unpublished Dissertation). University of Nairobi, Kenya.

Owen, S. A., \& Suchard, J. A. (2008). The Pricing and Impact of Rights Issues of Equity in Australia. Journal of Applied Financial Economics, 3, 1-39. https://doi.org/10.1080/09603100701537706

Owusu, N. V., \& Kuwornu, J. K. (2011). Analyzing the Effect of Macroeconomic Variables on Stock Market Returns: Evidence from Ghana. Journal of Economics and International Finance, 3(11), 605-615. http://www.academicjournals.org/JEIF

Patell, M. J. (1976). Corporate Forecasts of Earnings per Share and Stock Price Behavior: Empirical Tests. Journal of Accounting Research, 14(2), 246-256. https://doi.org/10.2307/2490543

Phillips, P. B., \& Perron, P. (1988). Testing for a Unit Root in Time Series Regression. Biometrika, 75, 335-346. https://doi.org/10.1093/biomet/75.2.335

Ramesh, S., \& Rajumesh, S. (2014). Information Content of Right Issue Announcements: A Study of Listed Companies in Colombo Stock Exchange of Sri Lanka. Research Journal of Finance and Accounting, 5(5), 154-162.

Reilly, F. K., \& Brown, K. C. (2011). Investment Analysis and Portfolio Management. Orlando: Harcourt Press.

Saunders, M., Lewis, P., \& Thornhill, A. (2009). Research Methods for Business Students. Harlow: Prentice Hall.

Shapiro, S., \& Wilk, M. B. (1965). An analysis of the Variance Test for Normality. Biometrica, 52(3), 591-611. https://doi.org/10.1093/biomet/52.3-4.591

Tahir, S. H., Sabir, H. M., Alam, T., \& Ismail, A. (2013). Impact of Firm's Characteristics on Stock Return: A Case of Non-Financial Listed Companies in Pakistan. Asian Economic and Financial Review, 3(1), 51-61.

Tepe, M. (2012). Market Reaction to Rights Offering Announcements in the Turkish Stock Market (Unpublished Dissertation). Middle East Technical University, Turkey.

Velayutham, E. (2015). Shareholder Wealth Effects of Rights Issues and Bonus Issues: Evidence From Sri Lanka. International Journal of Accounting and Business Finance, 2, 1-13. Retrieved from https://ssrn.com/abstract=2733950

Wright, R. E., \& Sylla, R. (2013). Corporate Governance and Stockholder/Stakeholder Activism in the United States. Daedalus, 142(2), 1790-1860.

\section{Copyrights}

Copyright for this article is retained by the author(s), with first publication rights granted to the journal.

This is an open-access article distributed under the terms and conditions of the Creative Commons Attribution license (http://creativecommons.org/licenses/by/4.0/). 